\title{
INFLUENCE OF LABOR LAW DOCTRINE ON DEVELOPMENT OF LABOR LEGISLATION
}

\author{
Oleksandra Pohorielova \\ Candidate of Juridical Sciences, Associate Professor, \\ Institute of Law of Taras Shevchenko National University of Kyiv, Ukraine \\ e-mail: a.pohorielova1@gmail.com,orcid.org/0000-0002-8927-9276
}

\section{Summary}

The article is devoted to the analyses of influence of labor law doctrine on development of labor legislation. It is stated that labor law doctrine is primary source of law in following cases: (a) enshrined in legislation of legal norms; (b) resolving legal cases in practice, particularly in judicial bodies. It is emphasized that the labor law doctrine has been forming and developing during process of analyses of (a) international legal norms and current legislation of the country and foreign countries; (b) domestic court practice and practice of European Court of Human Rights; (c) real relationship in the sphere of labor, which comply with the conditions of social and economic development of the country; (d) obtained in the past knowledge about the nature and regularity of development labor relationship and closely related relationship. It was concluded that the labor law doctrine as sectoral legal doctrine is logical continuation of legal doctrine in the government simultaneously exactly at the level of sectoral doctrine of law, legal ideas of modernity, which has the abstract character in the sphere of socially useful work, acquire the qualitatively new expression with its maximum adaptivity to implementing particular type of relationship in the sphere of labor.

Keywords: legal doctrine, doctrine of labor law, source of law, Romano-Germanic law system, labor legislation.

\section{DOI https://doi.org/10.23856/4326}

\section{Introduction}

Current conditions of development of Ukrainian statehood are characterized by reconsideration of values and place of law and doctrine among values. Undoubtedly the understanding the main role of legal regulation of social relationship, as a necessary condition of development of legal state. Regarding legal doctrine not everything is clear. Law as a regulator of social relation reflects these values in itself and level of social and cultural development, which is inherent for the society, but how the doctrine plays a role as a source of law? Particularly, what is the place of the doctrine of law at the system of law sources and how it influences the development of legislation and social relationship? The answer to these questions should give that science via grounding the influence of legal doctrine at the development of social relations within the framework of law. "Legal doctrine is conditioned by character of legal culture of the society, holistic and logically harmonized complex of recognized ideas and scientific views of law by legal society, which is the basis of professional legal conscientious and conceptual policy making, law enforcement and interpretation of law activities " (Great Ukrainian law encyclopedia: 20t, 2016, p. 471). It is caused by the necessity of analysis of features of sectoral doctrine, which is foundation for the development of labor legislation, and social relationships in the sphere of labor. 
Analysis of last researches and publications shows that the answers to the key issues regarding legal nature, essence, and characteristics of legal doctrine and sectoral legal doctrine are found its reflection in a five-volume edition of the National Academy of Legal Sciences of Ukraine "Legal Doctrine of Ukraine". Simultaneously legal doctrine cannot be considered as to be completely examined, and that is why such scientist as O.L. Boginich, O.O. Gubanov, M.V. Karmalita, M.M. Marchenko, E.U. Poliaskyi, O.M. Sydorenko, V.A. Trofimenko, E.M. Chernyh and other continue the analysis of the doctrine nature and the place in the system of sources of different legal systems, analyze the connection of legal doctrine with legal practice and other issues.

The aim of the article is to ground the legal influence of labor law doctrine at the development and improving the labor law.

\section{Results}

"Legal doctrine is one of the oldest textual sources of law, which still plays an extremely important role in legal regulation of social relations. Failure to recognize the legal doctrine as a formal source of law does not preclude its consideration as an existing and influenced phenomenon. Also, it influences not only at law enforcer and interpreter of current law and at the legislator. Obviously, that the level of the influence of legal doctrine and form if it expression at deferent countries are not the same" (Karmalita M., 2010, p. 6). Hence, during the process of analyses the essence of legal doctrine particularly and the doctrine of labor law, it is necessary to remember that the development of domestic doctrine of labor law should be performed in the context of that Ukraine belongs to Romano-Germanic law system, where the law (normative legal act) is the main source of law.

The concept of law, as M.N. Marchenko wrote, in Romano-Germanic law lies in that exactly law and not another law source (precedent, custom, doctrine, etc.) are placed at the prominent place in the process of formation and development of the current legal family and corresponding national legal system (Marchenko M.N., 2008, p. 472). Therefore, without denying the primacy of the normative legal act in the Romano-Germanic legal family, and accordingly in the legal system of Ukraine, its development still cannot be considered without taking into account the modern doctrine of law.

"Doctrine plays the role of theoretical foundation of the legislative and volitional activity of country, providing legislator with the terminological apparatus and first developments in the sphere of law. It could be said that the first normative acts were formalized consolidation of the main provision of the doctrine. However, in future, the doctrine lost its position as a source of law but received the same value in the field of legal methodology. At the level of methodology, its influence on the legislator shows new ways to influence it (Trofymenko V. A., 2009, p. 87)". It should be noted that the legislation as a result of volitional actions of policymakers is a result of comprehending actual social relations and making a decision on the need to provide these relations with a legal form. It can be argued with confidence that the development of legal ideas in specific socio-economic conditions determines the revision of state policy concerning objects of legal regulation. The doctrine of law "opens" the way for society to streamline social relations in accordance with the ideas about the necessary and socially significant. And it is thanks to scientific developments and the rooting of legal ideas that a rethinking of the normative order of interaction between participants in public relations takes place.

"One of the main features of Romano-Germanic law system is the presence of legal doctrine as genetical source of principles of law continental type. It is harmonized synthesis of 
theoretical and practical works. Taking care of problems of practice, the doctrine does not leave the problems of the development of the theory of law and vice versa (Karmalita M., 2010, p. 7). The doctrine of law is the source of new ideas regarding the conditions of the development of social essential relationship between citizens in the state, it coopts not only ideas of legal regulation and development of law, and "shows" the ways to reaching the aims of legal regulation. In its content, the doctrine of law grounds and justifies the necessity of new norms and improving existing legislation to comply with regularities of the development of social relationships. Simultaneously the doctrine of law in its nature is the reflection of legal reality where creative, intellectual results of activity of scientists are the conditions of transformation of lawmaking and law enforcement activity.

Doctrine integrally connects the dominated ideology in the society with practical activity, particularly, reformation of particular relationship does not occur spontaneously, and as a result of formed scientific results based on ideologist process in the government. For example, if dominated in society is the ideology of conservatism then legal regulation and legal ideas are directed on the saving the traditions of continuity in all spheres of social life. If e.g. libertarianism dominates then legal nature will explore and ground ideas of individual freedom and minimum influence of the government at the social relationship in government. Hence, as an origin of ideas regarding human rights and source of law in objective meaning, the doctrine of law is primarily in regards to the legislation but at the same time, it is not the source of law in the form of normative consolidation of human right.

The law could be named that by only legal norms, stated R. David, for those who count with reality and has wider, for our point of view, more correct view of the law, a doctrine at our days same as in the past, plays a very important role and is a vital source of law. Exactly the doctrine creates the vocabulary and legal definitions, which the legislator uses. Doctrine could influence legislators. In this case, the doctrine is only an indirect source of law. It would be difficult. Without distorting reality, deny the quality of the source of law (David R., 1988, p. 143).

Concurring with the statement of the scientist it should be noted that essential features of legal doctrine and doctrine of labor law particularly could be revealed via accepting as the base wide law implementation and understanding its destiny during process of regulation particular sphere of social life and as well as relationships which arise, change and end.

The main criteria which preconditioned the place of legal doctrine in the system of the law sources and accordingly the level of its importance and influence on other components of the legal system is the necessity of additional regulation of law relationship as a result of imperfection the main source of law. That is why within the framework of Roman-German legal system the legal doctrine plays not a big role comparatively, additional role, served as non-formalized additional source with the presence of the main source, particularly, normative legal act, which is maximally fully, comparatively with court precedent and religious norms, regulate all system of existing social relationship (Hubanov O.O., 2015, p. 14).

Admitting current statement it is necessary to add that the structure of legal system which includes subject of law, legal norms, and principles of law, legal relationship and legal behavior, legal consciousness, legal culture, etc. could not be developed without legal doctrine. Because in the society should the law and order prevail at the beginning, it is necessary to define the legal conditions of interaction between particular people who have rights and obligations. For such persons to become participants in legal relations, it is necessary to determine which circle of persons applies to this or that rule, and the rule itself should determine the measure of permissible behavior. For the purpose that such order of interaction takes place, it is necessary to turn to the legal doctrine, which will give an answer about the subjects of law, about their 
rights and obligations, which naturally arise in relations, and exactly doctrine gives the answer to the question of the social significance of these relations and, accordingly, it justifies, that social relationship which should be regulated.

In the context of this, it should be noted that the doctrine of labor law is the primary source for the formation of novel in labor law and simultaneously it is secondary in regarding to current legislation regarding labor. Priority of doctrine of labor law regarding legal innovation is explained that at the beginning at doctrine level formed definitions and conceptions were defined, subjects in particular types of relationship in the sphere of labor were described and based on dominated ideology formed legal ideas regarding content and volume and order of realization of labor rights. For the purpose that main source of law, particularly, normative legal act would define the rules of behavior of participant of relationship in the sphere of labor, it is necessary to explore and understand between whom the legal connection occurs in real vivid relationship and how this connection should provide vital circle or/and development of these relationships. It is essential not only to name the participants of the relationship in the sphere of labor and define the object of their relationship and consolidate the range of correspondent rights and obligations of the participant of the relationship. Because law realization needs the participation at this process at least two people who have a right to choose type and measure of the behavior which authorize subjects on making action and oblige them to act according to established and sanctioned at the government rules. Definition of correspondent connection according to the regularities at the relationship should be grounded and justified, and only after this in such connection legal form with definition of rights and obligation of subjects of law should be provided.

Legal doctrine as the phenomenon of legal reality and definition of legal science has undergone in its development. In the beginning, it was works of lawyers practice regarding common and casual interpretation current at that time law. There were, for the first time, works of famous Roman lawyers - Gaius, Justinian, Ulpianus. Later in connection with the twilight of the Roman Empire relay at the formation of legal doctrine cached up the professors of medieval universities where mainly legal science was formed of that time and there was adaptation of Rome law to those conditions of existing society. During period of formation of first national governments and corresponding legal systems legal doctrine as an individual source of law to give its place to national legislation, to written law. Later the role of legal doctrine at Romano-Germanic law system gradually declined, plays the subsidiary role regarding positive law. Simultaneously, particular statutes of legal doctrine were included, forming new condition, particularly, legal legislation (legal law) (Bohinich O. L., 2020, p. 287). The abovementioned confirms the primacy of doctrine of law and doctrine of labor law at the development of legislation, which is based on legal ideas of modernity improving the coexistence of the citizens at the society according to main social interests.

In labor law legal doctrine plays the main role regarding the determination of the content of labor law and its subject. It directly influences the conscience of the legislator, participants of labor, and connected relationship via the way of convictions and reward these subjects to determinate or change legal conditions of realization of rights in the sphere of labor.

Authority and common recognition of legal ideas regarding legal regulation of relations in the sphere of labor requires official consolidation via improving the legislation. It is explained by the fact that the doctrine of labor law is formed textually and has a written form of expression of legal ideas. Also, it is a result of analysis and research of relationships at their direct interconnection with modernity and regularity of relationships in the sphere of labor. Such regularities however include subject assessment of a particular scientist or group of scientists 
but they revealing the regularities of the development of relationship emphasizes attention at main features of the objects of the study which needs the development. Proposed authoritative scientists attempts of solution of legal problems or collision in the field of labor law allows not only discuss at the subject of improvement of legislation and also point at the ways with the help which formal clearness in particular relationship will facilitate its positive development.

Doctrine of labor law as an objective source of knowledge on regularity of development of labor and connected relationship and as a source of legal ideas regarding statutory normalization relationship in the sphere of law has been realized via state sanctioning, which has currently two ways at legislation and court practice.

Formation of legal doctrine as general performing during long time, crystallization of legal ideas proceeds during process of intellectual creative activity of the scientists. Purposefulness of the process of scientific way for improving the legislation and predicting of relationship in the sphere of labor gives it the qualities of the primary source of law. Because exactly doctrine reveals legal nature of the relationship in the sphere of labor by means legal methods show at legal possibility of realization of the rights of subjects in the sphere of labor.

E.U. Polianskii writes that "legal doctrine should be understood as a system of ideas and principles, also, as legal institutes, which are in inseparably mutual connection with legal science, legislation and practice and specify the main basics on which the legal state system is based. Doctrine traces origins at past, directly regulates law of modernity, recognizes the law of the future, and always functioning as a dynamic category that provides the following development and improvement of law. Legal doctrine of the government includes all knowledge which correspond to common requirements of current theory of law, which are reflected at legislation and used at the practice" (Polianskyi Ye.Iu., 2015, p. 311). "Phenomenon of legal doctrine maximally appears at its multi-aspect because it indeed expresses itself in different ways depending on the nature of social relations" (Polianskyi Ye.Iu., 2014, p. 13). Hence, if take into attention the fact that legal institutions are born and formed at the beginning by science, which in future could obtain the status of legal doctrine and legal idea precedes law principle. If to proceed from the fact that legal science and its doctrine statutes fulfill the practical task regarding improving current legislation then legal doctrine accordingly is secondary in relation to legal norms.

O.M. Sydorenko states that "doctrine is necessary to consider as a secondary source of law because it affects not only subjects applying and interpreting current law and legislator. That is why the role of legal doctrine should be improved as a source of law, legislative force, which determines the choice of the direction in legal regulation of social relationship, influences the character its development. In the legislative process, exactly doctrine should guarantee legal character of laws during their preparation, expert reviews, detection, disposal of collision and prevention. Members of legislative bodies apply to the doctrine during preparation and discussion drafts of law. Doctrine often is at the disposal of court bodies during decisions of controversial issues and during the formation of common principle of judge law. Direct and essential influence of law doctrine on law-making and law enforcement appeared in those cases when there is a deficiency in law (Sydorenko O.M., 2006, p. 42). Such approach confirms the importance of the legal doctrine as the source of law because exactly this source of law could be considered as commonly known and reliable. Simultaneously, usage of legal doctrine at lawmaking and law enforcement activity is willed actions which are willfully without force the subjects imply, realizing their authority.

Obligingness of legal doctrine, as E. M. Chernyh mentioned, this question, which is solved at the level of legal methodology. Descendental methodology of formal-procedural type 
on which the opposers rely on, obligingness of legal doctrine, evokes essential conceptual and empiric observation. Its insufficiency becomes specifically expressed at the perspective of value criteria which are required alternative approaches to law. At this coordination, it could be said about obligingness of legal doctrine at specifical meaning main but legally not absolute criteria, which obliges to choose ration and not forced necessity which he creates at the conscious (Chernykh Ye.M., 2016, p. 28). In fact, it confirms the problem of perception of legal doctrine as a source of law at Romano-Germanic law family however reveals the value of orientation of legal regulation of social relationship which indicates that usage of legal doctrine at the activity of state power depends on the level of social culture development at the society.

\section{Conclusions}

Abovementioned gives the reasons for following conclusions:

- doctrine of labor law as a legitimate phenomenon of past, current, and future development of law, is a source of legal ideas and knowledge about law relationship in the sphere of labor, legal patterns of development of these legal relationships, attempts of approval interests of the participants in labor and connected relationship, etc.;

- doctrine la labor law is primary source of law when it is: (a) enshrined in the legislation of legal norms; (b) and during resolving legal cases in practice, particularly in judicial bodies;

- doctrine of labor law is formed and developed during the process of analysis: (a) international-legal principles and current legislation of the government and international countries; (b) domestic court practice and practice of European Court of Human Rights; (c) real relationship in the sphere of labor which correspond with conditions of social and economic development of government; (d) obtained in the past knowledge about the nature and regularity of labor law and connected relationship;

- doctrine of labor law in theoretical aspect as a basic condition of formation of legal institutions in labor law is primary source and in law enforcement aspect is secondary. It is explained by multi-vector nature of legal influence of doctrine of labor law on development of labor law and relationship in the labor sphere. It is important to note that dynamism of doctrine of labor law and its multi-vector nature aimed at the development, not labor law as at the branch of legislation with formalized rules of behavior, it is aimed at development of labor rights of the participants of these relationships, realization of which, therefore, facilitate increasing the level of social-economic development at government;

- in case legal doctrine influences the formation of legal system, then sectoral doctrine doctrine of labor law affects the formation and development of system of labor law. We may conclude that unity and internal structuring labor law as branch law owning to doctrine of labor law, which ground and predicts following development of labor and connected relationship by improving legal principles merged at legal institutions, which distinguish similar relationship in the sphere of labor;

- doctrine of labor law as sectoral legal doctrine is logical continuation of legal doctrine in the state, simultaneously, at the level of sectoral doctrine of law legal ideas of modernity, which have abstract character in the sphere of socially useful labor, has acquire a quality new expression with its maximum adaptivity to implementation for particular type of relationship in the sphere of labor. 


\section{References}

Bohinich O. L. (2020) Rol pravovoi doktryny v yurydychnii praktytsi Ukrainy. [Role of legal doctrine in legal practice in Ukraine] Almanakh prava. Vyp. 11. S. 287-292.

Chernykh Ye.M. (2016) Oboviazkovist pravovoi doktryny yak problema metodolohii. [Obligingness of legal doctrine as an issue of methodology] Visnyk Natsionalnoi akademii pravovykh nauk Ukrainy. № 2 (85). S. 21-30.

David R. (1988) Osnovnye pravovye sistemy sovremennosti [Main legal systems of modernity] / per. s fr. i vstup. st. V. A. Tumanova. M.: Progress,. 496 s. [in Russian]

Hubanov O.O. (2015) Pravova doktryna yak dzherelo prava v mezhakh romano-hermanskoi, anhlosaksonskoi ta relihiino-tradytsiinoi pravovoi sim 'i: porivnialna kharakterystyka. [Legal doctrine within the framework of Romano-Germanic, Anglo-Saxon, religious, and natural law systems: competitive characteristic.] Pravo i suspilstvo. № 6. S. 9-14.

Karmalita M. (2010) Pravova doktryna u romano-hermanskii ta anhlosaksonskii pravovykh simiakh. [Legal doctrine in Romano-Germanic and Anglo-Saxon law systems] Pidpryiemnytstvo, hospodarstvo i pravo. 2010. № 2. S. 6-9.

Marchenko M.N. (2008) Ystochnyky prava: ucheb. posobye. [Law sources: tutorial] M.: TK Velby, Yzd-vo Prospekt, 760 s.

Polianskyi Ye.Iu. (2015) Pravova doktryna yak bazysna kontseptsiia prava: pryroda, struktura, znachennia. [Legal doctrine as basic concept of law: nature, structure, meaning] Naukovi pratsi Natsionalnoho universytetu «Odeska yurydychna akademiia». T. 17. S. 297-313.

Polianskyi Ye.Iu. (2014) Pro rozuminnia pryrody pravovoi doktryny v yurydychnii literaturi. [About understanding the nature of legal doctrine in legal literature.] Visnyk Zaporizkoho natsionalnoho universytetu. № 4 (I). S. 11-16.

Sydorenko O.M. (2006) Pravova doktryna yak vtorynne dzherelo prava. [Legal doctrine as secondary source of law] Aktualni problemy derzhavy i prava. 2006. Vyp. 29. S. 38-43.

Trofymenko V. A. (2009) Pravova doktryna yak osnova formuvannia pravovoi systemy Ukrainy. [Legal doctrine as the basis of formation of legal system of Ukraine] Visnyk Natsionalnoi yurydychnoi akademii Ukrainy im. Yaroslava Mudroho. Ser. Filosofiia, filosofiia prava, politolohiia, sotsiolohiia. № 2. S. 85-95.

Velyka ukrainska yurydychna entsyklopediia : 20 t. [Great Ukrainian law encyclopedia: 20t] (2016): Pravo, Kharkiv. T. 3 : Zahalna teoriia parava. [Common theory of law] redkol.: O.V. Petryshyn (holova) ta in. ; Nats. akad. prav. nauk Ukrainy ; In-t derzhavy i prava imeni V.M. Koretskoho NAN Ukrainy ; Nats. yuryd. un-t imeni Yaroslava Mudroho. 2017. 952 s. [in Ukrainian] 